\title{
MOLECULAR MECHANISMS OF STEM CELL AGING
}

\author{
Katerina Jazbec, Mojca Jež, Mojca Justin, Primož Rožman \\ Blood transfusion centre of Slovenia, Šlajmerjeva 6, 1000 Ljubljana, Slovenia \\ ${ }^{*}$ Corresponding author, E-mail: primoz.rozman@ztm.si
}

\begin{abstract}
The aging of multicellular organisms is a complex process, which is a result of various mutually complementary causes. One of these causes is the aging of stem cells. The biological function of stem cells is the replacement of cells that are lost due to illness, injury or normal fluctuations in the maintenance of tissue homeostasis. Molecular mechanisms involved in stem cell aging are similar to those involved in the aging of somatic cells. They include DNA damage and mutations, cell senescence, stem cell exhaustion, telomere shortening, epigenetic changes (alterations of histones and DNA and the consequent dysregulation of gene expression), changes in microRNAs, changes in metabolism, nutrient sensing, decline in mitochondrial integrity and biogenesis, alterations in microenvironment, accumulation of paracrine factors, and loss of cell polarity and proteostasis. Stem cells have developed special mechanisms that compensate for age-related accumulations of errors and they manage to maintain their stemness for a long time, however, they are able to keep cells in a good condition only for a limited period. This article describes the various mechanisms of stem cell aging and their consequences.
\end{abstract}

Key words: stem cell; aging; nutrient sensing; niche

\section{Introduction}

Stem cells (SC) have the ability to go through numerous cell cycles while maintaining an undifferentiated state (self-renewal) and the capacity to differentiate into specialized cell types, which is referred to as potency. In contrast to more differentiated daughter cells, SCs are theoretically regarded as "immortal" and can go through an unlimited number of divisions. In tissues they replace cells lost due to homeostatic turnover (fast renewing tissues) or due to injury and disease. With age, their ability to self-renew declines and their ability to differentiate into various cell

Received:21 March 2018

Accepted for publication: 5 September 2018 types is altered, which can lead to degeneration and dysfunction of the aging tissues and organs. Molecular mechanisms involved in the aging of adult SCs are very similar to the mechanisms involved in the aging of other somatic cells. Aging is caused by various factors that interact and operate simultaneously. Molecular mechanisms that cause cell aging include DNA damage and mutations, cell senescence, exhaustion of the stem cell pool, telomere shortening, epigenetic changes (alterations of histones, DNA and the consequent dysregulation of gene expression), changes in microRNAs, changes in metabolism, nutrient sensing, decline in mitochondrial integrity and biogenesis, alternations in microenvironment and paracrine factors, as well as loss of cell polarity and proteostasis (Figure 1) $(1,2)$. 


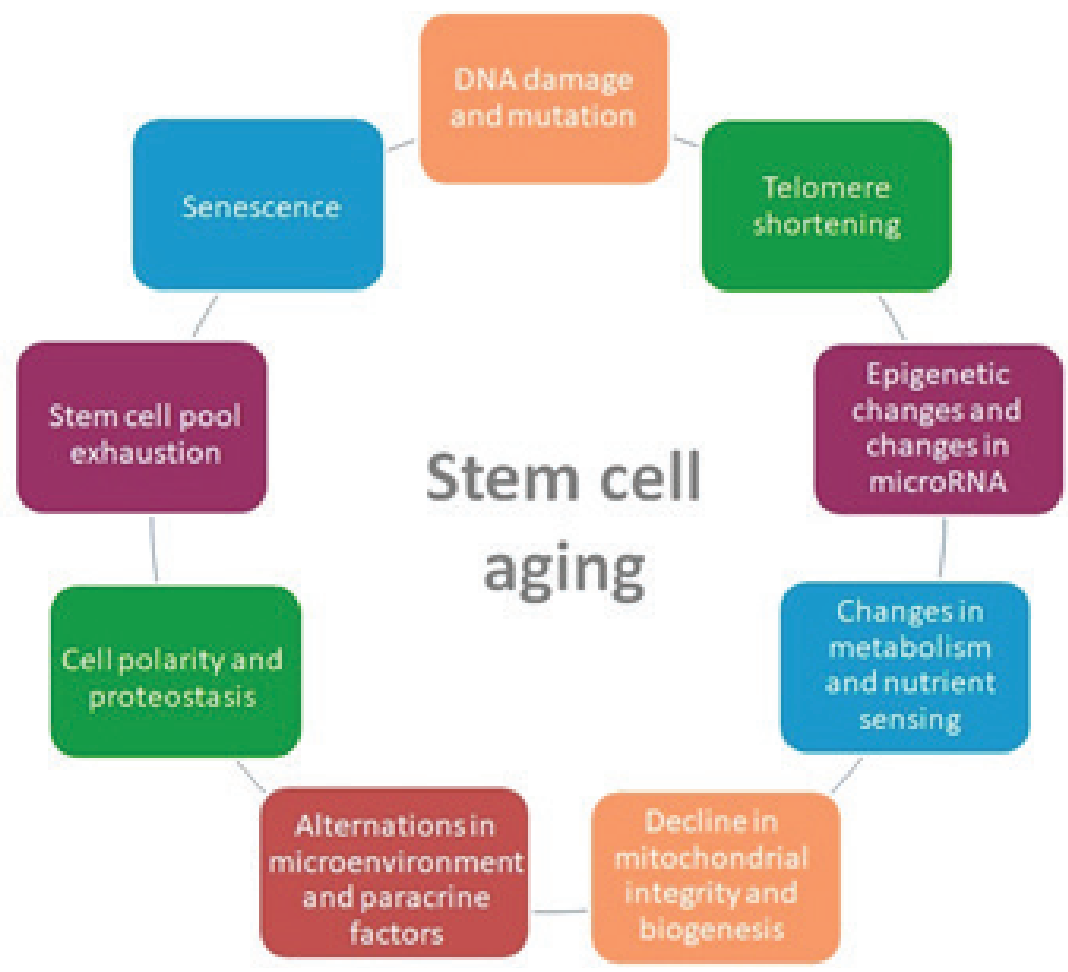

Figure 1: Mechanisms involved in the aging of stem cells

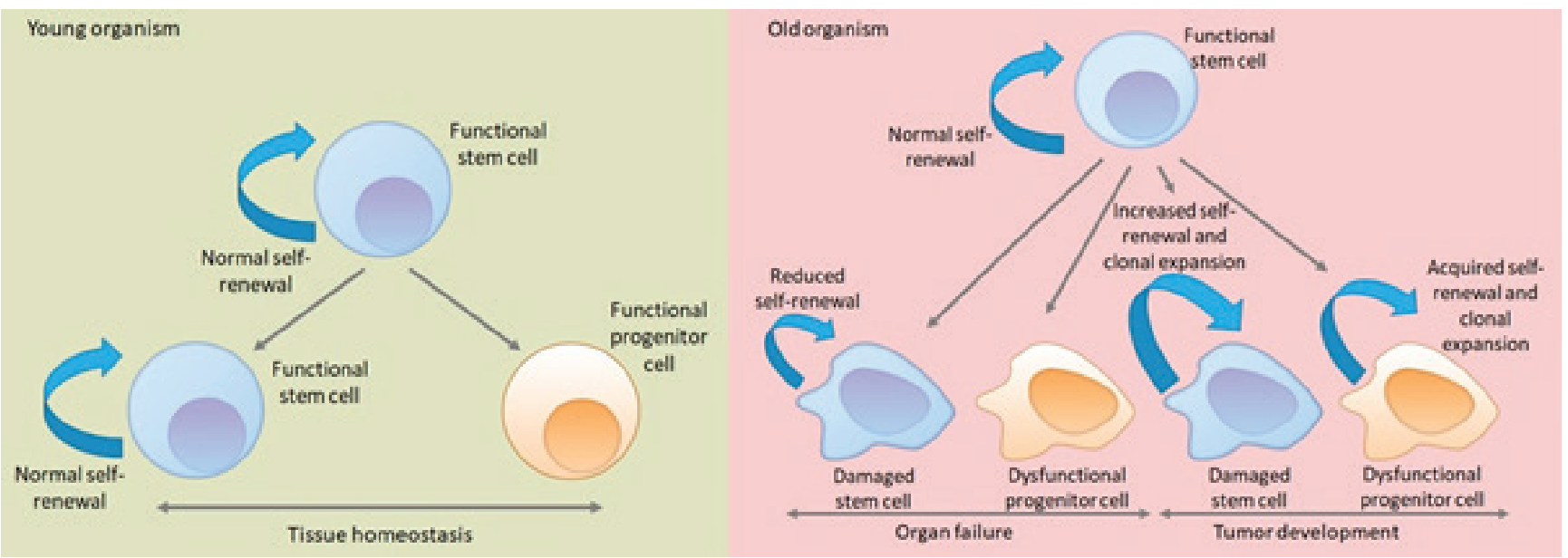

Figure 2: The accumulation of mutations reduces the functionality of stem cells

\section{Stem Cell Aging}

\section{Exhaustion of stem cell pool}

One of the many theories of aging, the so called "Stem cell theory of aging", proposes that a decline in the ability of different types of SCs to efficiently regenerate tissues contributes to the aging of organs and the whole organism (3). This inability to regenerate tissues is mostly caused by changes in the production of specialized progenitors, and in some cases, by a decline in the number of SCs.

One of the major discoveries in recent years showed an age-related decline in the number of hematopoietic stem cell (HSC) clones whereas in a normal adult approximately 10000 clones are available. The study of hematopoiesis in a 115 years old woman demonstrated that the majority of her white blood cells were the offspring of just two HSC clones. Furthermore, telomeres of her white blood cells were significantly shorter 
than telomeres of other somatic cells (4). Aging is also associated with a decline in the number of circulating CD34+ hematopoietic stem and progenitor cells. Mandraffino and colleagues (2017) monitored 100 octogenarians and demonstrated that the number of their circulating CD34+ progenitor cells was a better predictor of their lifespan than other risk factors, such as blood pressure, smoking, and cholesterol levels (5). In our study, we also observed a decline in the number of CD271+ cells (mesenchymal stem/ stromal cells) with increasing age (unpublished). It is now becoming clear that maintaining a sufficient pool of functional SCs contributes to extended longevity and a longer health span.

\section{DNA damage and mutations}

In most mammalian cells, spontaneous mutations in DNA occur on a daily basis. Many of them are repaired by DNA repair mechanisms, but some persist. Mutations accumulate throughout life and are responsible for many age-related cellular events. The "DNA damage theory of aging" was one of the first theories to explain the process of aging (6). DNA damage can be caused by external factors (ionizing radiation, ultraviolet radiation, or environmental toxins) or by a cell's own metabolic processes (for example, by the accumulation of reactive oxygen species that are generated during the mitochondrial respiration process). Old SCs with accumulated mutations are still functional up until the DNA alterations affect the essential regulatory genes, which cause them to become dysfunctional. Clonal expansion of the damaged stem and progenitor cells can lead to cancer and tumor development. A decrease in their ability to self-renew and the consequent production of dysfunctional progenitor cells leads to organ failure (Figure 2) (7).

\section{Telomere shortening}

Telomeres are repetitive sequences at the end of the chromosomes that maintain chromosome stability and protect chromosomes from undesirable recombination and fusion with each other. In most somatic cells, telomeres shorten with each cell division, which limits the number of somatic cell divisions. In contrast to differentiated somatic cells, adult stem (and cancer) cells express the enzyme telomerase, which catalyzes the extension of telomere sequences and theoretically enables an unlimited number of cell divisions. However, despite the action of telomerase, it has been demonstrated that telomeres in SCs also shorten with time (8). When telomeres reach a certain shortened length, the cell enters a state of senescence, stops dividing, and can become apoptotic. Though there is a lot of evidence that telomere shortening is inversely related to lifespan, the direct association of telomere length with aging still remains controversial. Researchers have developed mice without the telomerase RNA gene (TERC) and did not find any age-related phenotypes in comparison to the wild type mice (9), which leaves this an open issue.

We have also determined telomere length and expression of telomerase in old and young CD34+ cells intended for autologous transplantation but the telomere length did not correlate with the success of cell therapy (10).

\section{Epigenetic changes and changes in microRNA}

Epigenetic changes include altered DNA methylation profiles, histone modifications, chromatin remodeling, and changes in microRNA (miRNA). Alterations in epigenetic regulation lead to SC dysfunction and an increased risk of developing hematologic cancer diseases (3). For example, an age-related increase in trimethylation of lysine 4 on the histone $\mathrm{H} 3$ protein subunit (H3K4me3) has been found to be associated with a loss of differentiation ability (11).

miRNAs are small noncoding RNAs that regulate the posttranscriptional expression of target genes and are important in the regulation of SC self-renewal and differentiation. They tend to be altered in aged stem cells. It has been demonstrated that some miRNAs inhibit the translation of target mRNAs in SCs and their differentiating daughter cells. This miRNAs function was proven in embryonic and in various adult SCs (12).

\section{Decline in mitochondrial integrity and biogenesis}

Many studies have demonstrated that mitochondrial dysfunction is one of the major 
factors contributing to the aging of cells. Evidence shows that a decline in mitochondrial functions is caused by an accumulation of mutations in mitochondrial DNA (mtDNA), an increase in oxidative damage, a decrease in the number and function of mitochondria, a destroyed calcium homeostasis and a failure in mitochondria dynamics (fusion and division), all of which may contribute to the aging process $(13,14,1)$.

Despite many studies, the exact pathophysiological link between damage in mtDNA and aging is still unclear. Mutations in mtDNA are difficult to detect because every mutation is unique and their detection would be possible only if every mitochondria produced the same mutation. Nevertheless, these mutations can be detected in induced pluripotent stem cell (iPS) lines because in the process of iPS derivation, researchers use clones of individual blood or skin cells. Every iPS cell derived from the same cell thus contains the same mutations in mtDNA as the original adult cell (15).

The "Free radical theory of aging" describes aging as a result of an increased production of reactive oxygen species (ROS) and subsequent increased oxidative damage in aging cells. However, it is still unclear if an increased production of ROS is a cause or the result of aging. While high levels of ROS can cause oxidative damage to the main cellular components, such as DNA, proteins and lipids, a mild increase in ROS formation during stress can help an organism to survive and does not have a negative effect on longevity. In fact, it can even prolong its lifespan $(13,16)$. This concept is known as mitochondrial homeostasis or mitohormesis $(17,18)$.

\section{Changes in metabolism and nutrient sensing}

SCs, like other cells, generate energy via glycolysis or oxidative phosphorylation. Dormant SCs mostly use glycolysis as the main process for generating energy. This is probably because fewer ROS are generated during this process. Perhaps, due to this fact, most SCs reside in hypoxic environments $(19,20)$. When there is an increased need for energy (for example, when cells start to proliferate), SCs switch from glycolysis to oxidative phosphorylation, which makes them more susceptible to oxidative damage.
Glucose is the main cell nutrient. Many ageassociated regulatory mechanisms maintain concentration of glucose at physiological levels. There is an age-related decrease in hormone levels, including growth hormone and its secondary mediator IGF-1 (insulin like growth factor 1). The presence of glucose induces the insulin/IGF-1 signaling (IIS) pathway. The IIS pathway is one of the most evolutionary preserved pathways, which controls aging. The main targets are the FOXO family of transcription factors and the mammalian target of rapamycin (mTOR) complexes. Mutations and a decrease in levels of expression of those key targets promote longevity. At the same time, mutations in genes for the same targets can lead to uncontrolled cell division and cancer development (21). There are three additional, related and interconnected nutrientsensing systems that participate in glucosesensing: the mTOR signaling pathway, which senses high amino acid concentrations; the AMPK (AMP-activated protein kinase) signaling pathway, which senses low energy states by detecting high AMP levels; and the sirtuin pathway, which senses low energy states by detecting high NAD+ levels (22). Researchers managed to increase longevity in yeast, nematodes and fruit flies by lowering mTOR1 expression levels. Similarly, longevity was increased in mice which received the mTOR inhibitor rapamycin $(23,24)$. By promoting catabolic processes, the AMPK and sirtuin pathways have an opposite effect to the IIS and mTOR pathways. An increased expression of AMPK and sirtuins promote healthy aging (25), whereas the anabolic activity, induced by the IIS and mTOR1 pathways seem to be a major accelerator of aging.

One of the most robust interventions that delays aging in diverse species from yeast to mammals, is caloric restriction. It is defined as a reduction in caloric intake while maintaining essential nutrient requirements. Research in this area has discovered molecules - small-molecule caloric restriction mimetics (rapamycin, metformin) that provide health benefits and extended lifespan without food intake reduction. It has been shown that these molecules extend the lifespan in mice (24). Caloric restriction also has a positive impact on functions of different populations of $\mathrm{SC}$, for example it increases the number of satellite cells in muscles and improves the function of HSC and germinal SC in fruit flies $(26,27)$. Caloric 
restriction influences SC function through the IIS pathway, mTOR signaling pathways, AMPK, sirtuins, and FOXO transcriptional activity. To summarize, signaling pathways involved in anabolic processes accelerate aging, while limited caloric intake promotes longevity (28).

\section{Alterations in microenvironment and the effect of paracrine factors}

Similarly, as aging affects SCs, it also affects the microenvironment, the so called SC niche. The bone marrow niche consists of mesenchymal stromal/ stem cells (MSC), osteoblasts, adipocytes, other stromal cells, and extracellular matrix. The ability of the MSCs to proliferate declines with age, whereas the number of adipocytes in the bone marrow increases $(29,30,31)$. Molecular mechanisms that promote aging of the $\mathrm{SC}$ niche are probably similar to mechanisms involved in the aging of other types of cells (for example, accumulation of ROS, etc.). The extent to which the aged bone marrow niche contributes to the aging of HSCs has not yet been fully explained. One of the main reasons is the inaccessibility of the niche in the bone marrow, its complex architecture and its three-dimensional geometry. It has been demonstrated that the old microenvironment has a negative effect on SC engraftment after transplantation. When young HSC were transplanted into an aged niche, HSCs had less success in engrafting and repopulating the niche, and they also exhibited enhanced myelopoiesis (32). One of the many mechanisms of aging is associated with alterations in adhesions between SCs and niche cells. An aged bone marrow niche also contributes to the loss of HSC polarity, skewing toward myeloid differentiation, expansion of granulocyte-macrophage progenitor cells and dysfunction in lymphocytes B differentiation (33, $34,35,36)$.

Various circulating factor levels also have an influence on the aging of SCs. Many of them were identified because of their rejuvenating effects detected in the blood or plasma of young animals, or animals on caloric restriction diets. Experiments with parabiosis in mice demonstrated that a decline in neural and muscle SC function in old mice can be reversed by circulating factors from young mice $(37,38)$. It has been observed that most of the therapeutic effects after transplantation probably occur due to soluble factors and are not a result of direct integration of transplanted cells (39).

\section{Cell polarity and proteostasis}

Proteostasis is a mechanism that regulates the proper folding, functioning, and degradation of cellular proteins through regulated protein translation, chaperone assisted protein folding, and protein degradation pathways. Many researchers have demonstrated that proteostasis alters with age, and there is consequently an accumulation of misfolded or damaged proteins (40). The accumulation of unfolded or misfolded proteins results in the development of some agerelated diseases, such as Alzheimer's disease, Parkinson's disease, and cataracts (41). The activity of the two main proteolytic systems, the autophagy-lysosomal system, and the ubiquitinproteasome system, involved in protein quality control, also declines with age $(42,43)$.

To prevent the accumulation of the damaged components, SCs have developed a mechanism called asymmetric segregation. After an asymmetric division, the damaged components are distributed into the differentiating cell, whereas the SC remains youthful $(6,44)$. In this way, SCs have been shown to asymmetrically segregate damaged proteins and mitochondria. In order to divide asymmetrically, the cell has to be polarized. The ability of HSCs to polarize decreases with age, and one of the reasons for this are alterations in the Wnt signaling pathway (45).

SCs also have high autophagy and proteasome activity. Both processes participate in the degradation of damaged proteins. Increased autophagy activity was found in HSC and skin SCs (46), while increased activity of proteasome was found only in embryonic SCs and has not been described in adult SCs (47).

\section{Cellular senescence}

Cellular senescence is defined as an arrest of the cell cycle. It is triggered by various stress factors like telomere shortening, ROS, damage of nuclear DNA, activation of certain oncogenes or reactivation of tumor suppressor genes. Senescent cells secrete different pro-inflammatory cytokines and chemotactic factors, which are recognized by the immune cells, which then destroy the senescent cell.

When a cell loses its tumor suppressor defense, which includes proteins $\mathrm{p} 53$, retinoblastoma proteins, and telomeres, it enters senescence. If 
a cell does not enter senescence, its telomerases reactivate, or the cell develops an alternative path of telomere lengthening, it can become malignant (48). In addition to apoptosis, senescence is therefore one of the beneficial mechanisms that contribute to the removal of damaged and potentially oncogenic cells under normal conditions. However, it contributes to the plethora of aging mechanisms if it is not compensated for by a renewal of cells.

\section{Conclusion}

We have witnessed major progress in the development of advanced cell therapies in recent decades. SCs that are used by clinicians for various cell-therapies need to be of the best quality, meaning that cell products should not contain senescent or other dysfunctional cells. Understanding the SC aging processes will have a major impact on the quality of advanced cell therapies. It will also affect the selection of donors donating cells for therapies. On the other hand, the quality of cells could be improved by the process of rejuvenation, using the counter-aging mechanisms.

One of the major goals in science today is to improve the quality of life of the aging population. In the future, we will probably be able to rejuvenate tissues and organs. This will improve the healthspan, and consequently increase the lifespan of people. Science will soon establish whether SCs are the "fountain of youth" people have been in search of for over a thousand of years.

\section{Acknowledgements}

The work was supported by the Slovenian Research Agency (Grant No. P3-0371).

\section{References}

1. Lopez-Otin C, Blasco MA, Partridge L, et al. The hallmarks of aging. Cell 2013; 153: 1194-217.

2. Rozman JZ, Perme MP, Jez M, et al. The effect of CD34+ cell telomere length and hTERT expression on the outcome of autologous CD34+ cell transplantation in patients with chronic heart failure. Mech Ageing Dev 2017; 166: 42-7.

3. Ahmed AS, Sheng MH, Wasnik S, et al. Effect of aging on stem cells. World J Exp Med 2017; 7: 1-10.
4. Holstege H, Pfeiffer W, Sie D, et al. Somatic mutations found in the healthy blood compartment of a 115-year-old woman demonstrate oligoclonal hematopoiesis. Genome Res 2014; 24 : $733-42$.

5. Mandraffino G, Aragona CO, Basile G, et al. CD34+ cell count predicts long lasting life in the oldest old. Mech Ageing Dev 2017; 164: 139-45.

6. Schultz MB, Sinclair DA. When stem cells grow old: phenotypes and mechanisms of stem cell aging. Development 2016; 143: 3-14.

7. Burkhalter MD, Rudolph KL, Sperka T. Genome instability of ageing stem cells-induction and defence mechanisms. Ageing Res Rev 2015; 23: 29-36.

8. Flores I, Canela A, Vera E, et al. The longest telomeres: a general signature of adult stem cell compartments. Genes Dev 2008; 22: 654-67.

9. Ju $Z$, Jiang $H$, Jaworski $M$, et al. Telomere dysfunction induces environmental alterations limiting hematopoietic stem cell function and engraftment. Nat Med 2007; 13: 742-7.

10. Sun D, Luo M, Jeong M, et al. Epigenomic profiling of young and aged HSCs reveals concerted changes during aging that reinforce self-renewal. Cell Stem Cell 2014; 14: 673-88.

11. Gangaraju VK and Lin H. MicroRNAs: key regulators of stem cells. Nat Rev Mol Cell Biol 2009; 10(2):116-25.

12. Srivastava S. The Mitochondrial basis of aging and age-related disorders. Genes (Basel) 2017; 19: 8(12).

13. Kujoth GC, Hiona A, Pugh TD, et al. Mitochondrial DNA mutations, oxidative stress, and apoptosis in mammalian aging. Science 2005; 309: 481-4.

14. Kang E, Wang X, Tippner-Hedges R, et al. Age-related accumulation of somatic mitochondrial DNA mutations in adult-derived human iPSCs. Cell Stem Cell 2016; 18(5):625-36.

15. Doonan R, McElwee JJ, Matthijssens F, et al. Against the oxidative damage theory of aging: superoxide dismutases protect against oxidative stress but have little or no effect on life span in Caenorhabditis elegans. Genes Dev 2008; 22: 3236-41.

16. Ristow M, Schmeisser K. Mitohormesis: promoting health and lifespan by increased levels of reactive oxygen species (ROS). Dose Response 2014; 12: 288-341.

17. Sevini F, Giuliani C, Vianello D, et al. mtDNA mutations in human aging and longevi- 
ty: controversies and new perspectives opened by high-throughput technologies. Exp Gerontol 2014; 56: 234-44.

18. Jang YY, Sharkis SJ. A low level of reactive oxygen species selects for primitive hematopoietic stem cells that may reside in the low-oxygenic niche. Blood 2007; 110: 3056-63.

19. Jez M, Rozman P, Ivanovic $Z$, et al. Concise review: the role of oxygen in hematopoietic stem cell physiology. J Cell Physiol 2015; 230: 1999-2005.

20. Aunan JR, Watson MM, Hagland HR, et al. Molecular and biological hallmarks of ageing. $\mathrm{Br}$ J Surg 2016; 103: e29-46. https://onlinelibrary. wiley.com/doi/full/10.1002/bjs. 10053

21. Houtkooper RH, Williams W, Auwerx J. Metabolic networks of longevity. Cell 2010; 142: 9-14.

22. Johnson SC, Rabinovitch PS, Kaeberlein M. mTOR is a key modulator of ageing and age-related disease. Nature 2013; 493: 338-45.

23. Harrison DE, Strong ZD, Sharp JF, et al. Rapamycin fed late in life extends lifespan in genetically heterogeneous mice. Nature 2009; 460: $392-5$.

24. Alers S, Loffler AS, Wesselborg S, et al. Role of AMPK-mTOR-Ulk1/2 in the regulation of autophagy: cross talk, shortcuts, and feedbacks. Mol Cell Biol 2012; 32: 2-11.

25. Chen J, Astle CM, Harrison DE. Hematopoietic senescence is postponed and hematopoietic stem cell function is enhanced by dietary restriction. Exp Hematol 2003; 31: 1097-103.

26. Mair W, McLeod CJ, Wang L, et al. Dietary restriction enhances germline stem cell maintenance. Aging Cell 2010; 9: 916-8.

27. Fontana L, Partridge L, Longo VD. Extending healthy life span-from yeast to humans. Science 2010; 328: 321-6.

28. Stenderup K, Justesen J, Clausen C, et al. Aging is associated with decreased maximal life span and accelerated senescence of bone marrow stromal cells. Bone 2003; 33: 919-26.

29. Naveiras O, Nardi V, Wenzel PL, et al. Bone-marrow adipocytes as negative regulators of the haematopoietic microenvironment. Nature 2009; 460: 259-63.

30. Guerra DA, Paiva AE, Sena IFG, et al. Adipocytes role in the bone marrow niche. Cytometry A 2018; 93(2):167-71.

31. Woolthuis CM, de Haan G, Huls G. Aging of hematopoietic stem cells: intrinsic changes or micro-environmental effects? Curr Opin Immunol 2011; 23: 512-7.

32. Liang Y, Van Zant G, Szilvassy SJ. Effects of aging on the homing and engraftment of murine hematopoietic stem and progenitor cells. Blood 2005;106: 1479-87.

33. Rossi DJ, Bryder D, Zahn JM, et al. Cell intrinsic alterations underlie hematopoietic stem cell aging. Proc Natl Acad Sci U S A 2005; 102: 9194-9.

34. Li F, Jin F, Freitas A, et al. Impaired regeneration of the peripheral $\mathrm{B}$ cell repertoire from bone marrow following lymphopenia in old mice. Eur J Immunol 2001; 31: 500-5.

35. Guidi N, Sacma M, Standker L, et al. Osteopontin attenuates aging-associated phenotypes of hematopoietic stem cells. EMBO J 2017; 36: 1463.

36. Conboy IM, Conboy MJ, Wagers AJ, et al. Rejuvenation of aged progenitor cells by exposure to a young systemic environment. Nature 2005; 433: 760-4.

37. Villeda SA, Luo J, Mosher KI, et al. The ageing systemic milieu negatively regulates neurogenesis and cognitive function. Nature 2011; 477: 90-4.

38. Lavasani M, Robinson AR, Lu A, et al. Muscle-derived stem/progenitor cell dysfunction limits healthspan and lifespan in a murine progeria model. Nat Commun 2012; 3: e608. https:// www.nature.com/articles/ncomms 1611.pdf

39. Koga H, Kaushik S, Cuervo AM. Protein homeostasis and aging: the importance of exquisite quality control. Ageing Res Rev 2011; 10: 205-15.

40. Powers ET, Morimoto RI, Dillin A, et al. Biological and chemical approaches to diseases of proteostasis deficiency. Annu Rev Biochem 2009; 78: 959-91.

41. Rubinsztein DC, Marino G, Kroemer G. Autophagy and aging. Cell 2011; 146: 682-95.

42. Tomaru U, Takahashi S, Ishizu A, et al. Decreased proteasomal activity causes age-related phenotypes and promotes the development of metabolic abnormalities. Am J Pathol 2012; 180: 963-72.

43. Moore DL and Jessberger S. Creating age asymmetry: consequences of inheriting damaged goods in mammalian cells. Trends Cell Biol 2017; 27: 82-92.

44. Florian MC, Nattamai KJ, Dorr K, et al. A canonical to non-canonical Wnt signalling switch in haematopoietic stem-cell ageing. Nature 2013; 
503: 392-6.

45. Salemi S, Yousefi S, Constantinescu MA, et al. Autophagy is required for self-renewal and differentiation of adult human stem cells. Cell Res 2012; 22: 432-5.

46. Vilchez D, Simic MS, Dillin A. Proteostasis and aging of stem cells. Trends Cell Biol 2014; 24: 161-70.

47. Sharpless NE, Depinho RA. Telomeres, stem cells, senescence, and cancer. $\mathrm{J}$ Clin Invest 2004; 113: 160-8.

\title{
MOLEKULARNI MEHANIZMI STARANJA MATIČNIH CELIC
}

\author{
K. Jazbec, M. Jež, M. Justin, P. Rožman
}

Povzetek: Staranjevečceličnih organizmovjekompleksen proces, kije posledica različnih, med seboj dopolnjujočih sevzrokov. Eden od teh je tudi staranje matičnih celic, katerih biološka funkcija je nadomeščanje celic, ki propadejo zaradi bolezni, poškodb ali normalnega obnavljanja pri ohranjanju homeostaze tkiv. Molekularni mehanizmi, ki so vpleteni v staranje matičnih celic, so podobni kot pri staranju telesnih celic. Vključujejo poškodbe DNK in mutacije, celično senescenco, izčrpavanje zalog matičnih celic, krajšanje telomer, epigenetske spremembe (spremembe histonov in DNKA ter posledično spremenjeno izražanje genov), spremembe v mikroRNK, spremembe v zaznavanju hranil in presnovi, zmanjšano število mitohondrijev in njihovo oslabljeno funkcijo, spremembe v mikrookolju in kopičenje različnih parakrinih dejavnikov ter izgubo celične polarnosti in proteostaze. Matične celice so razvile posebne mehanizme, s katerimi kompenzirajo s staranjem povezano kopičenje napak in ohranjajo svojo matičnost, vendar jih ti mehanizmiv dobri kondiciji lahko ohranjajo le določen čas. V članku opisujemo različne mehanizme staranja matičnih celic in njihove posledice.

Ključne besede: matične celice; staranje; hranilna snov; zaznavanje; niša 